\title{
Post-harvest regeneration of montane Abies amabilis forests in northern Washington, $\mathrm{USA}^{\mathbf{1}}$
}

\author{
Ella Elman ${ }^{2}$ and David L. Peterson ${ }^{3}$
}

The effects of regeneration treatments on current stand composition were analyzed in a high-elevation forest approximately 20 years after harvest in the Cascade Range, Mt. Baker-Snoqualmie National Forest, Washington (USA). Post-harvest treatments included sites that were (1) broadcast burned and planted with Abies amabilis, (2) unburned and seeded with A. amabilis and A. procera, and (3) unburned and planted with A. amabilis. All sites are currently dominated by A. amabilis and Tsuga heterophylla. Burned-planted sites have a smaller proportion of A. amabilis than unburned sites, and burned sites have less advance regeneration of all species than unburned sites. Although future stand composition is difficult to predict, comparison with historical stand data for this location indicates that regeneration treatments, including seeding and planting, have not had significant effects on overstory species dominance. If rapid regeneration of A. amabilis is a management objective, then post-harvest burning should be avoided to encourage advance regeneration of this species.

\section{Key words: Abies amabilis, forest regeneration, subalpine forest}

Les effets des traitements de régénération sur la composition actuelle des peuplements ont été analyses dans les forêts de haute altitude environ 20 ans après récolte dans la Mt Baker-Snoqualmie National Forest, située dans la chaîne des Cascades dans l'État de Washington aux États-Unis. Les traitements post-récolte comprenaient (1) le brûlage dirigé et la plantation d'Abies amabilis, (2) aucun brûlage et ensemencement d'A. amabilis et d'A. procera, et (3) aucun brûlage et plantation d'A. amabilis. Toutes les stations sont présentement dominées $\operatorname{par} A$. amabilis et Tsuga heterophylla. Les stations brûlées et plantées ont une plus faible proportion d'A. amabilis que les stations non brûlées, et les stations brûlées ont moins de régénération préétablie que les stations non brûlées. Même si la composition future des peuplements est difficile à prédire, la comparaison avec les données historiques des peuplements pour cette région indique que les traitements de régénération, comprenant l'ensemencement et la plantation, n'ont eu aucun effet significatif sur la dominance des espèces formant le couvert. Si une régénération rapide de l'A. amabilis constitue un objectif d'aménagement, alors le brûlage post récolte devrait être évité afin d'encourager la régénération préétablie de cette espèce.

Mots-clés : Abies amabilis, régénération forestière, forêt subalpine

\section{Introduction}

Over the past 50 years, an increasing number of timber harvests in national forests of the western United States have occurred in high-elevation ecosystems. Many management techniques previously used in low-elevation coniferous forests were transferred to high-elevation stands. For instance, slash burning for site preparation and planting Pseudotsuga menziesii (Mirb.) Franco (Douglas-fir), which was formerly standard practice in low-elevation forests, has proved ineffective at high elevations due to high tree mortality, stem and form defects, and slow postharvest growth (Boecksteigel 1982, Arnott et al. 1995). The effects of forest management activities on high-elevation forests have not been adequately studied, due to the lower commercial value of these stands for wood production compared to lowelevation systems. This study examines regeneration in highelevation forests 20 years following harvest to understand the effects of past harvest treatments on forest composition.

${ }^{1}$ Paper presented at "Mountain Forests: Conservation and Management," IUFRO Silviculture Conference, Vernon, British Columbia, Canada, July 28-August $1,2002$.

${ }^{2}$ University of Washington, College of Forest Resources, Box 352100, Seattle, WA 98195 (USA).

${ }^{3}$ USDA Forest Service, Pacific Northwest Research Station, 400 N. $34^{\text {th }}$ St., Suite 201, Seattle, WA 98103(USA). Email: wild@u.washington.edu (Corresponding author)

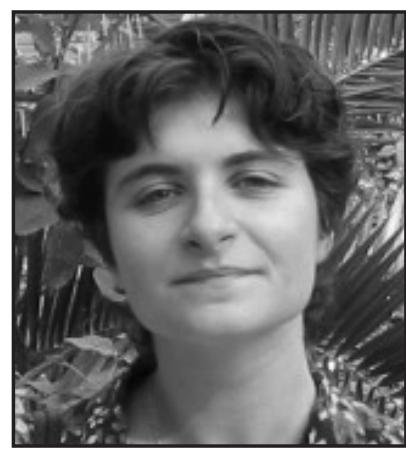

Ella Elman

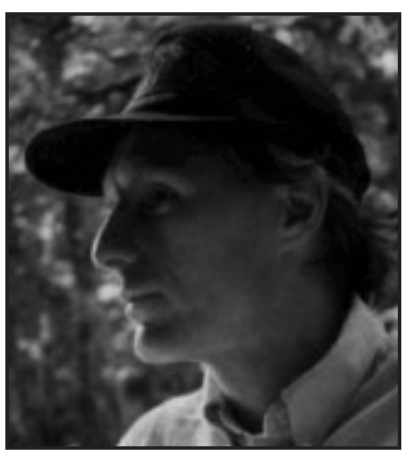

David L. Peterson

\section{Methods}

Eighteen sites, clearcut from 1973 to 1987, encompassing three common post-harvest treatments, were examined in the Mt. Baker-Snoqualmie National Forest, Washington (USA) at elevations ranging from $830 \mathrm{~m}$ to $1460 \mathrm{~m}$ (Table 1). Treatments included: 1) sites that were broadcast burned and planted with Abies amabilis Dougl. ex Forbes (Pacific silver fir) or Abies procera Rehd. (noble fir), 2) unburned sites that were seeded with $A$. amabilis or A. procera and 3) unburned sites that were planted with A. amabilis.

Sampling was conducted during August and September 2000. Three $100-\mathrm{m} \times 5-\mathrm{m}$ belt transects were systematically placed in each clearcut, and were located at least $30 \mathrm{~m}$ from for- 


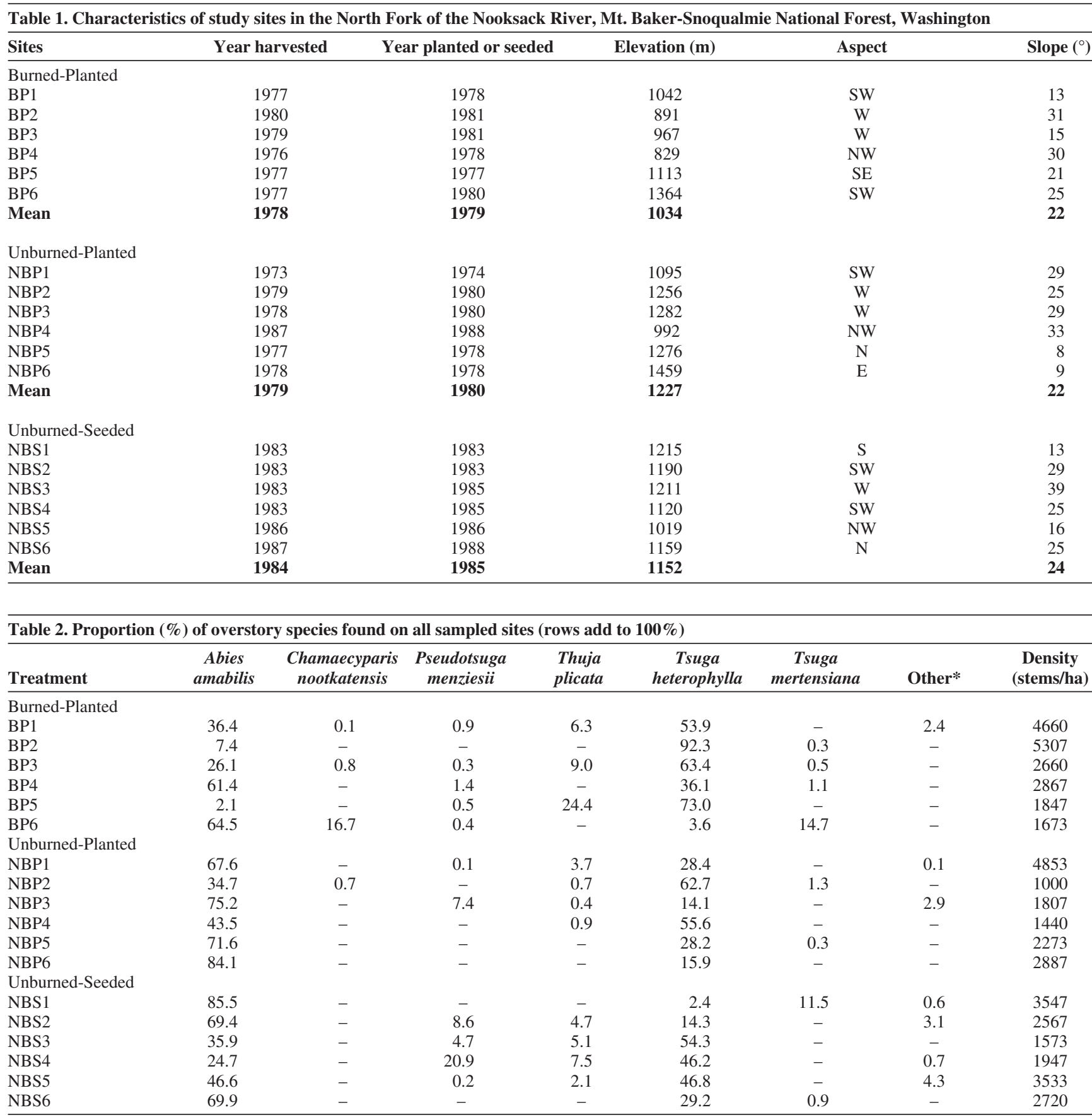

* "Other" category is comprised of Abies procera and Prunus emarginata, which make up less than 5\% of trees on any site.

est and road edges in order to avoid edge effects. All trees and seedlings (any tree below the shrub canopy layer) along the transect were tallied and identified. Trees were measured with callipers or diameter tape, and placed into one of eleven diameter classes. A total of 7374 trees were surveyed.

Six 2-m $\times 2-m$ plots were established in each transect. Plots were spaced $20 \mathrm{~m}$ apart along the transect, with the first plot placed at the beginning of the transect. Dbh and height of three trees closest to each plot were measured, and increment cores were extracted to determine age of regeneration on the site. Height and age data were obtained from 835 trees over the course of the study.
One-way analysis of variance (ANOVA) was used to detect differences among post-harvest treatments. Proportional data were transformed using the arcsin square-root transformation. Mean dbh and height of advance regeneration and planted trees across sites were compared using t-tests. Tests were considered significant at $\alpha<0.1$. Proportional data were transformed using the arcsin square-root transformation.

\section{Results}

All sites are dominated by A. amabilis and Tsuga heterophylla (Raf.) Sarg. (western hemlock), which represent $68-100 \%$ of all trees present (Table 2). Tree density varies from 1000 to 5305 

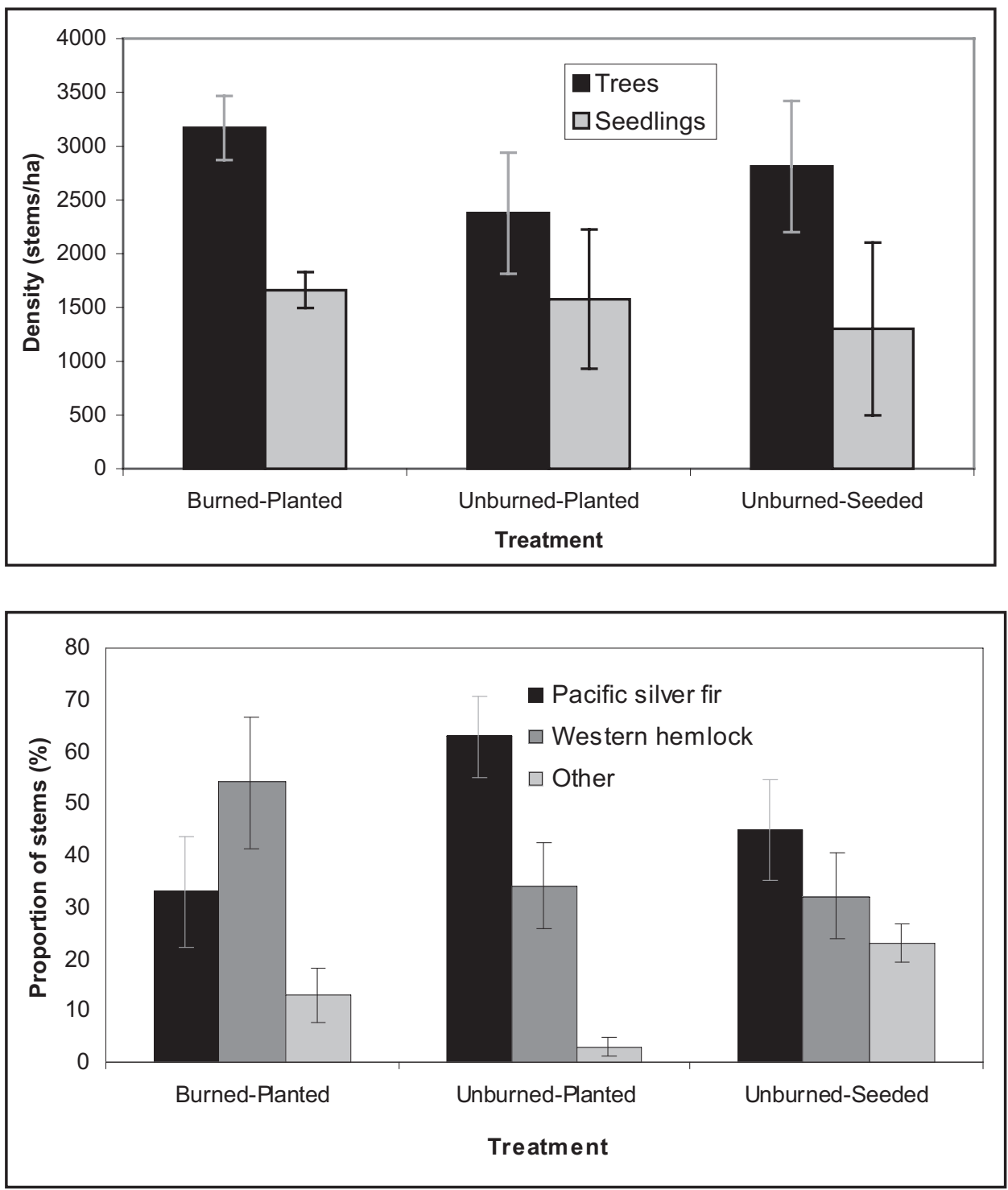

Fig. 1. Mean tree and seedling density across treatments. Bars represent 1 S.E. of the mean
Fig. 2. Mean proportion of stems of Abies amabilis and Tsuga heterophylla across treatments. Bars represent 1 S.E. of the mean trees/ha. Seedling density ranges from 213 to 5567 seedlings/ha. Density for both trees and seedlings is similar between treatments (Fig. 1).

The mean dbh is similar across treatments $(4.4 \mathrm{~cm})$, and ranges from 0.1 to $31 \mathrm{~cm}$ for the burned-planted and unburned-seeded treatments, and from 0.1 to $46 \mathrm{~cm}$ for the unburned-planted treatment. The mean height across treatments is $5.6 \mathrm{~m}$, ranging from 1 to $21 \mathrm{~m}$ on burned-planted sites, from 1 to $25 \mathrm{~m}$ on the unburned-planted sites, and from 1 to $15 \mathrm{~m}$ on the unburnedseeded sites.

On burned-planted sites, a smaller proportion of A. amabilis is found than on unburned-planted sites $(\mathrm{p}=0.058, \mathrm{n}=18)$ (Fig. 2). Burned sites also contain significantly less advance regeneration than unburned sites $(\mathrm{p}<0.001, \mathrm{n}=18)$. Only two of the burned-planted sites have advance regeneration $(3.1 \%$ of all trees cored), whereas $37.2 \%$ and $48.0 \%$ of the trees on unburnedplanted and unburned-seeded sites, respectively, are of advance regeneration origin. As a result, burned-planted sites have the youngest trees (mean age of 16.9 years $\pm 0.53 \mathrm{~S}$.E.), while the mean age of trees on unburned-planted and unburned-seeded sites is higher $(24.0 \pm 1.14$ and $21.1 \pm 1.07$ years old respectively). Both height and dbh of advance regeneration is significantly larger than planted trees on non-burned sites ( $p$ $=.007, \mathrm{n}=12$ and $\mathrm{p}=.002, \mathrm{n}=12$ respectively). Burned sites were not compared due to lack of advance regeneration.

Records obtained from the Mt. Baker-Snoqualmie National Forest were used to reconstruct pre-harvest overstory species composition of mature forests in the study area. Comparison with Forest Service stand data for the study sites indicates that to date widespread planting and seeding of A. amabilis have not had significant effects on overstory species composition (Table 3).

\section{Discussion \\ Overstory}

Burned-planted sites have less A. amabilis than unburnedplanted sites. Higher densities of T. heterophylla and Thuja plicata Donn ex D. Don (western redcedar) on burned-planted sites may indicate that these species compete favourably with A. amabilis on these sites, possibly due to higher soil temperatures at burned sites (Zabowski et al. 2000). Natural regeneration of $A$. amabilis tends to have higher vigour than 
Table 3. Historical stand composition reconstruction of the proportion (\%) of overstory species found on sampled sites (rows add to 100\%) (USDA Forest Service, Sedro-Wooley, WA)

\begin{tabular}{|c|c|c|c|c|c|}
\hline Treatment & Abies amabilis & Pseudotsuga Menziesii & Thuja plicata & Tsuga heterophylla & Tsuga mertensiana \\
\hline BP1 & 60 & - & - & 40 & - \\
\hline BP2 & 30 & - & - & 70 & - \\
\hline BP3 & 56 & - & - & 44 & - \\
\hline BP4 & 39 & - & 4 & 57 & - \\
\hline BP5 & 19 & - & - & 81 & - \\
\hline BP6 & 58 & - & - & 11 & 31 \\
\hline NBP1 & 37 & 10 & 6 & 47 & - \\
\hline NBP2 & 47 & - & - & 43 & 10 \\
\hline NBP3 & 24 & 39 & 10 & 27 & - \\
\hline NBP4 & 45 & - & - & 55 & - \\
\hline NBP5 & 66 & - & - & 34 & - \\
\hline NBP6 & 84 & - & - & - & 16 \\
\hline NBS1 & 22 & - & - & 12 & 66 \\
\hline NBS2 & 1 & 61 & 13 & 25 & - \\
\hline NBS3 & 90 & 1 & - & 9 & - \\
\hline NBS4 & 39 & - & - & 61 & - \\
\hline NBS5 & 36 & - & 23 & 41 & - \\
\hline NBS6 & 44 & - & 13 & 43 & - \\
\hline
\end{tabular}

planted stock (Arnott et al. 1995, Koppenaal et al. 1995) in terms of growth and nutrient accumulation. Because sites that were not burned have a significantly higher amount of natural regeneration, it is not surprising that there is more $A$. amabilis present on those sites.

The burned sites experienced a lag time between harvest and stand establishment of approximately 4.5 years, even though they were planted from one to two years later. Almost all trees other than A. amabilis on the burned sites have regenerated from seed, which can require several years for germination and successful establishment. In nurseries, approximately three years are required to grow $A$. amabilis seedlings to plantable stock (Boecksteigel 1982). On high-elevation sites, where conditions are less favourable than in a nursery and growth is slow, it can take longer for seedlings to establish, as was the case on these sites. Keeping a healthy stock of advance regeneration appears to cut down the time for stand establishment considerably, especially since advance regeneration trees have greater height and dbh than planted stock.

\section{Historical comparisons}

Historical records indicate that prior to cutting, stands in this study were 250 to over 300 years old, with approximately 16-41 trees/ha ranging from 56 to $79 \mathrm{~cm} \mathrm{dbh}$. Current stocking is sufficient to replicate historical conditions. Overstory species composition following harvest and planting is not significantly different from historical composition. Due to the young age of these stands, it is difficult to speculate on their species composition 10,50 or 100 years in the future. Several decades of monitoring would be necessary to accurately assess the effects of timber harvest and post-harvest management activities on species composition. If species composition drastically changes in the future, thinning or planting of appropriate species are options to consider.

\section{Managing high-elevation stands for timber harvest}

In order to have minimum impact on the ecological functions of high-elevation forests, it is important to incorporate management practices appropriate for these forest ecosystems into harvest and post-harvest management. Several inferences and recommendations emerge from this study.
1) Regeneration and growth are slow in high-elevation forests. True firs grow very slowly in the juvenile phase and can take up to 20 years to reach breast height (Harrington and Murray 1982). Slow rates of regeneration and growth mean that several decades may be needed to achieve desired stand (stocking) density. Recent research has shown that tree spacing may need to be regulated to achieve optimal growth of $A$. amabilis (Curtis et al. 2000). Partial cutting, shelterwood cutting, and green tree retention in high-elevation areas (McCaughey et al. 1991, Mitchell 2001) can improve regeneration and growth of shade-tolerant species such as A. amabilis and T. heterophylla. However, it is also apparent that further research is needed to find the optimal density and basal area of green trees to provide adequate shade but not suppress tree growth.

2) Advance regeneration is an important component on all unburned sites, and should be encouraged at moderate densities, particularly because at high elevations natural regeneration performs better than planted stock (Arnott et al. 1995, Koppenaal et al. 1995). In addition, all seedlings originate from adjacent mature stands, as planted trees are too young to produce seed. Logging operations should be planned carefully to avoid damaging advance regeneration by limiting mechanical site preparation (Herring and Etheridge 1976). Unmerchantable materials should be scattered on sites to provide better conditions for seedling establishment and advance regeneration.

3) Nitrogen is a limiting factor in montane ecosystems and has been linked to poor growth in A. amabilis (Hawkins et al. 2002). Burning high-elevation sites can result in nutrient loss and potential effects on long-term productivity (DeByle 1974, Vogt et al. 1989). On our sites, broadcast burning killed or greatly reduced all advance regeneration, leading to slower stand initiation and growth. Furthermore, density of $A$. amabilis is reduced on burned sites, indicating that it does not establish well following fire.

\section{References}

Arnott, J.T., R.K. Scagel, R.C. Evans and F.T. Pendl. 1995. High elevation regeneration strategies for subalpine and montane forests of coastal British Columbia. B.C. Min. For., Victoria, B.C. FRDA Rep. No. 229. 
Boecksteigel, L. 1982. Management experience on Abies amabilis from the Forest Service - Mt. Baker-Snoqualmie view. In C.D. Oliver, R.M. Kenady (eds.). Proceedings of the Symposium on the Biology and Management of True Fir in the Pacific Northwest. Contribution No. 45. pp. 305-309. University of Washington, Seattle.

Curtis, R.O., G.W. Clendenen and J.A. Henderson. 2000. True fir-hemlock spacing trials: Design and first results. USDA For. Serv. PNW Res. Sta. GTR-492.

DeByle, N.V. 1974. Soil fertility as affected by broadcast burning following clearcutting in Northern Rocky Mountain larch/fir forests. In Proceedings of Tall Timbers Fire Ecology Conference (Pub. 1976). Tall Timbers Res. Sta., Tallahassee Florida. 14: 447-464.

Harrington, C.A. and M.D. Murray. 1982. Patterns of height growth in western true firs. In C.D. Oliver and R.M. Kenady. (eds.). Proceedings of the Symposium on the Biology and Management of True Fir in the Pacific Northwest. Contribution No. 45. pp. 209-214. University of Washington, Seattle.

Hawkins, B.J., R.S. Koppenaal and A.K. Mitchell. 2002. Proximity to a stand edge influences growth of advance and planted Pacific silver fir seedlings. NW Sci. 76: 221-229.

Herring, L.J. and D.E. Etheridge. 1976. Advance amabilis-fir regeneration in the Vancouver Forest District. B.C. For. Serv., Can. For. Serv. Joint Report No. 5.
Koppenaal, R.S., B.J. Hawkins and A.K. Mitchell. 1995. Acclimation of natural and planted Amabilis fir to clearcut and stand edge microclimates on a coastal montane reforestation site. Can. For. Serv., Victoria. FRDA Rep. No. 232.

McCaughey, W.W., C.E. Fiedler and W.C. Schmidt. 1991. Twenty-year natural regeneration following five silvicultural prescriptions in spruce-fir forests of the intermountain west. USDA For. Serv. Intermountain Res. Sta. Res. Paper INT-439.

Mitchell, A.K. 2001. Growth limitations for conifer regeneration under alternative silvicultural systems in a coastal montane forest in British Columbia, Canada. For. Ecol. and Manage. 145: 129-136.

Vogt, K.A., E. Moore, S. Gower, D. Vogt, D. Sprugel and C. Grier. 1989. Productivity of upper slope forests in the Pacific Northwest. In D. Perry (ed.). Maintaining the Long-term Productivity of Pacific Northwest Ecosystems. pp.137-163. Timber Press, Portland.

Zabowski, D., B. Java, G.Scherer, R.L. Everett and R. Ottmar. 2000. Timber harvesting residue treatments: Part 1 . Responses of conifer seedlings, soils and microclimate. For. Ecol. and Manage. 126: $25-34$. 